\title{
Reproduction performance of sows inseminated with stress gene-free semen given probiotic- supplemented feed
}

Julius V. Abela*

\begin{abstract}
Submitted: 12 October 2019 | Accepted: 09 June 2020

This study generally aimed to assess the effect of supplementation with various levels of a novel product containing probiotic and yeast cells, a feed enzyme, short-chain oligosaccharides, and herbal extracts (Farmer Peck's Performance Booster ${ }^{\circledR}$ ) and the use of halothane free gene semen on two successive parities in sows in selected farms in Leyte. Randomized complete block design (RCBD) with treatment used in $\mathrm{T}_{0}$ - (in-feed antibiotics, $0 \mathrm{~g}$ probiotic/kilogram feed and Al using semen from farm's boar); $T_{1}-(0$ antibiotics, $2 \mathrm{~g}$ probiotic/kilogram feed and $\mathrm{Al}$ with halothane free gene semen) and $\mathrm{T}_{2}-(0$ antibiotics, $3 g$ probiotic/kilogram feed and Al with halothane free gene semen). The study results showed that sow-litter performance of artificially inseminated sows using halothane free gene semen in two farrowing seasons was significantly higher in $\mathrm{T}_{1}$ and $T_{2}$ groups than that of $T_{0}$ group as affected by probiotic supplementation. Probiotic supplementation, both at $2 \mathrm{~g} \mathrm{~kg}^{-1}\left(\mathrm{~T}_{1}\right)$ and $3 \mathrm{~g} \mathrm{~kg}^{-1}\left(\mathrm{~T}_{2}\right)$ of feed is effective in improving both litter and sow performance. The cost of using halothane free gene semen for Al is less as compared to using semen from the farm's boar, and the cost of using probiotic at two levels as feed additive is relatively lower than using antibiotics based on the pre-weaning mortality, litter size, and litter weight at weaning. The use of halothane free gene semen can now be widely used in the different piggery farms. Including the use of probiotic supplement for both the sows and piglets.
\end{abstract}

Keywords: probiotic supplementation, artificial insemination, halothane free gene semen, swine production

'Department of Animal Science, Visayas State University, Visca Baybay City, Leyte

*Corresponding Author. Address: Department of Animal Science, Visayas State University, Visca Baybay City, Leyte; Email: docjulsgrebitabela@gmail.com

DOI: $10.32945 /$ atr42212.2020 


\section{INTRODUCTION}

At present, the fastest and cheapest way to achieve heterosis through crossbreeding is by artificial insemination (Al). As with other animals, Al in pigs offers many advantages in different fields the greatest of which is gaining access to superior genetics (Knox 2000).

The stress gene is a recessive gene found in some breeds of pigs that affects the animal's susceptibility to stress and lead to porcine stress syndrome (PSS). It is also called halothane gene because it can be tested by exposing the pigs to the anesthetic halothane (Zhang et al 1992). The stress susceptible HAL $n$ allele is associated with reduced body fat in pigs (Kathirvel \& Archibald 2001). The swine stress gene (hal) is located in chromosome 6 (p1.1-q2.1) and codes for ryanodine receptors, which are $\mathrm{Ca}^{2+}$ release channels of skeletal muscle sarcoplasmic reticulum. Comparison of sequence of full-length hal cDNA (Genbank M91451) from PSS susceptible and PSS non-susceptible pigs revealed 18 single nucleotide polymorphisms between these two types of pigs. One of the polymorphisms involves the substitution of cytosine (PSS non-susceptible) by a thymine (PSS susceptible) at nucleotide 1843. This alteration results in the replacement of an arginine at position 615 by a cysteine. As a consequence, in recessive homozygote's $(n n)$ the gene hal leads to PSS and the major post-mortem manifestation of pale, soft and exudative pork (PSE) (Marriott \& Schilling 2006). In heterozygosis $(\mathrm{Nn})$, the hal gene produces lower carcass quality but possibly higher carcass weight. The polymorphism at nucleotide 1843 of the hal gene has recently been characterized by a DNA test using blood or a muscle biopsy as the source of genomic DNA (Bastos et al 2000). Fisher et al (2000) reported that the effect of the halothane gene Initial bacon gain in pumped weight was significantly higher $(p<0.001)$ for the $\mathrm{NN}(15.2 \%)$ and $\mathrm{Nn}(14.9 \%)$ compared to the nn pigs $(8.9 \%)$. Similarly, the total gain in bacon yield was the highest for the $\mathrm{Nn}(11.5 \%)$ and NN pigs $(10.0 \%)$, and significantly higher $(p<0.05)$ than the bacon from nn pigs $(3.4 \%)$. Fàbrega et al (2002) reported that for improving meat quality and welfare the halothane gene should be removed from breeding schemes in order to obtain production of piglets that are less susceptible to stress, better performance, and improved meat quality and welfare. De Smet et al (1996) reported that halothane genotype Belgian Landrace and Pietrain pigs were predominant in meat quality traits. Garcia-Macias et al (1996) and Larzul et al (1997) also reported that halothane genotype had a significant effect on meat quality of the pigs. Bidanel et al 2020 reported the differences in crossbreeding for meat quality traits were in favor to Meishan (MS) genes.

Probiotic products for various livestock production systems were introduction mostly as feed supplement and in swine, mostly for piglets (Ho 2004). As with antibiotics, the primary reason for their use is to improve intestinal health by modifying the composition of the resident intestinal microbes (Böhmer et al 2006). It is a well-established fact that the health of the gastrointestinal tract generally affects the health of the animal (Altemueller et al 2009). Several studies have already been conducted to determine the effect of dietary supplementation with probiotics in swine and in other livestock species (Estienne et al 2005). These studies used either the lactobacillus species or the yeast cells (Jacela et al 2010). Simon (2005) used the above microorganisms alone or in combination with other ingredients including probiotics, enzymes or herbal extracts. 


\section{Reproduction performance of sows inseminated with stress gene-free semen}

This paper reports the effects of supplementation with various levels of a novel product containing probiotic and yeast cells, a feed enzyme (Alpha-Amylase, IUB No. 3.2.1), short-chain oligosaccharides, and herbal extracts and the use of stress gene-free PIC GTC semen on two successive parities in sows in selected farms in Leyte. In this study, probiotic is a preparation of or a product containing viable, defined microorganisms in sufficient numbers, which alter the micro flora (by implantation or colonization) in a compartment of the host and by that exert beneficial health effects in this host (Schrezenmeir \& de Vrese 2001).

\section{MATERIALS AND METHODS}

\section{Experimental Animals}

The Gene Transfer Corporation (GTC) semen used in treatment two (2) and three (3) is halothane free gene or coming from PIC pigs with Stress Free proper name (Ter 2009). Production of piglets includes those that are less susceptible to stress, better performance, and improved meat quality and welfare (Kathirvel \& Archibald 2001). Clutter et al (2007) reported that in crossbreeding crossbred pigs is widely accepted and recommended practice in commercial swine production. The enrolled farms had crossbred sows for this study and were chosen purposively using the following criteria:

First, the three farms had at least eighteen heads sows served as experimental animal around 2-3 years old and into their second parity with eighteen sows to be bred around January and March 2009 (Batch 1) and the same eighteen sows (Batch 2 ) in June and August 2009. The sow was not a repeat breeder in its first production cycle and the farm owner agreed to use the halothane free gene semen for artificial insemination in the $T_{1}$ and $T_{2}$ sows and the probiotic supplement treatments, for two reproductive cycles starting on the day of artificial insemination until weaning day of the third cycle. A total of 54 heads of sows were used in this study to complete the batch 1 and batch 2 farrowings. All the semen samples from GTC were evaluated upon arrival and prior to insemination. Only semen that had met the minimum criteria of $70 \%$ motility and $80 \%$ morphology were used including farm's boar semen. The piggery farm at DAS-CAFS Visayas State University, Gaas piggery farm at Barangay Gaas, Baybay, Leyte and Tabgas piggery farm at Barangay Tabgas, Albuera, Leyte had never used halothane free gene semen in the past. The Al was done by only one person across three treatments and all parameters such as Littersize at Birth Born Alive (LSBBA) and Littersize at Weaning (LSW) within and among farms were properly counted on the number of piglet heads per sow. The Litter Weight at Birth (LWB) and Litter Weight at Weaning (LWW) within farms were accounted per head using calibrated hog weighing scale in kilogram. Pre-weaning Mortality (PWM) was by counting the number of pre-weaning deaths of the piglets among the litters in three farms. Lactational Weight Loss (LWL) was accomplished by getting the sow's weight after farrowing minus the actual body weight after the successful lactation and weaning the piglets. Weaning-to-Conception Interval (WCl) was the post-partum successful mating of the sows and Number of Service per Litter (SPL) was counted on the mating and the conduct of Al services per sow. Breeding to Breeding Interval (BBI) was accompanied by the period of first mating or Al plus the number of days of gestation period, lactation period, post-partum days 
until the next successful mating or breeding of the sow. Litters produced per sow per year (LPPSY) was the sow index or the number of parity of the per year and Pigs Produced per Sow per Year (PPSY) was the number of piglets produced in the sow index.

Second, the farm was using gestating and lactating commercial feeds for its sows and pre-starter feed for the litter and no changes would be made on feeding management during the experimental period. Sow diet was pelleted but piglet diet was in crumbled form; gestating sows and lactating sows were fed restrictively according to their body mass and piglets had ad libitum access to pre-starter feed from day 15 to 30 . The sow and litter were kept in individual farrowing pens provided with a crate for the sow and a creep area for the litter with partition in between. The farm followed a thirty (30) day lactation period; and the research was allowed access to farm records on the experimental animals.

\section{Experimental Design}

A total of fifty-four 2-3 years old lactating sows were used in the study for three experimental farms (Table 1). From each of these farrow-to-finish farms, fifty-four sows from each farm were into their second parity and expected to be in-heat each within the months of January and March 2009 (Batch 1), and June and August (Batch 2) 2009. The fifty-four sows in three farms were randomly distributed to the three treatment groups and were observed during their second and third parities. The sows in DAS-CAFS, Ga-as, and Tabgas piggery farm were crossbreds of unknown percentage of mixed breed of Landrace, Large White, Pietrain, and Poland China.

Table 1. Experimental layout in three farms showing the block allocation

\begin{tabular}{|c|c|c|c|c|c|c|}
\hline Treatments & \multicolumn{3}{|c|}{$\begin{array}{c}\text { Second Heat/Parity } \\
\text { (January and March } \\
\text { 2009) }\end{array}$} & \multicolumn{3}{|c|}{$\begin{array}{c}\text { Third Heat/Parity } \\
\text { (June and August } \\
\text { 2009) }\end{array}$} \\
\hline $\begin{array}{l}2 \mathrm{~kg}^{-1} \text { teed, Dynamutilin } 10 \% \text { teed premix } \\
\text { at } 3 \mathrm{~g} \mathrm{~kg}^{-1} \text { feed \& Lincomycin } 4.4 \% \text { feed } \\
\text { premix at } 1 \mathrm{~g} \mathrm{~kg}^{-1} \text { feed); } 0 \mathrm{~g} \text { probiotic/kilogram } \\
\text { feed and Al using semen from farm's boar) }\end{array}$ & S1 & S4 & S7 & S10 & S13 & S16 \\
\hline $\begin{array}{l}\mathrm{T}_{1} \text { - }(0 \text { antibiotics; } 2 \mathrm{~g} \text { probiotic/kilogram feed } \\
\text { and } \mathrm{Al} \text { with halothane free gene semen })\end{array}$ & $\mathrm{S} 2$ & S5 & S8 & S11 & S14 & $\mathrm{S} 17$ \\
\hline $\begin{array}{l}\mathrm{T}_{2} \text { - (0 antibiotics; } 3 \mathrm{~g} \text { probiotic/kilogram feed } \\
\text { and } \mathrm{Al} \text { with halothane free gene semen })\end{array}$ & S3 & S6 & S9 & $\mathrm{S} 12$ & S15 & $\mathrm{S} 18$ \\
\hline
\end{tabular}

Note: Both these boar/semen sources have met the minimum standard by the author.

The fifty-four sows in three farms were randomly distributed to the three treatment groups as follows: $T_{0}$-farm's practice (in-feed antibiotics, $0 \mathrm{~g}$ probiotic/kilogram feed and $\mathrm{Al}$ using semen from farm's boar); $\mathrm{T}_{1}-0$ antibiotics, $2 \mathrm{~g}$ probiotic/kilogram feed and $\mathrm{Al}$ with halothane free gene; and $\mathrm{T}_{2}-0$ antibiotics, $3 \mathrm{~g}$ probiotic/kilogram feed and Al with halothane free gene semen. 


\section{Reproduction performance of sows inseminated with stress gene-free semen}

For the sows in $\mathrm{T}_{0}$ (in-feed antibiotics, $0 \mathrm{~g}$ probiotic/kilogram feed and $\mathrm{Al}$ using semen from farm's boar, table 1), the brand of the gestating or lactating feed was the choice of the farm. This feed was mixed with the antibiotic additives and without the probiotic (Taras \& Simon 2007), while $T_{1}$ and $T_{2}$ sows had the antibiotic additive replaced with the probiotic supplement.

Aside from the $\mathrm{Al}$ and probiotic supplementation, the gestating and lactating feeding and other management practices of the enrolled farms were not modified except for the administration of Vitamin ADE on the $70^{\text {th }}, 95^{\text {th }}$ and $110^{\text {th }}$ day of gestation, vaccination against hog cholera on the $90^{\text {th }}$ day of gestation (at $2 \mathrm{~mL}$ per head regardless of body weight) and deworming on the $97^{\text {th }}$ day using Ivermectin ${ }^{\circledR}$ at $1 \mathrm{~mL}$ per $33 \mathrm{~kg}$ body weight.

Frequency counts and relative frequency, percentages and means were used for descriptive statistics. In addition, data obtained from the two successive parities or in this case, the second and third reproductive cycles of the two batches of sows each in three treatment groups were subjected to univariate ANOVA for a randomized complete block design while Tukey's HSD was used for treatment means comparison.

\section{RESULTSANDDISCUSSION}

\section{Litter Performance}

\section{Litter Size at Birth Born Alive (LSBBA) and Litter Size at Weaning (LSW)}

The univariate ANOVA showed that at $(p<.05)$ the treatments caused significant differences in litter size at birth born alive (LSBBA) in the two farms. Tukey's HSD analysis revealed that $T_{1}$ and $T_{2}$ were significantly higher than those in $\mathrm{T}_{0}$ but not from each other.

Table 2 and table 3 shows the mean of LSBBA and LSW of the piglets in the three treatment groups in the three farms. In the three farms, $T_{1}$ and $T_{2}$ LSBBA and LSW were significantly higher than those of $\mathrm{T}_{0}$ at $p<0.05$ significant level.

Thus, in three farms which crossbred sows did not benefit much from heterosis since the semen used in them including those in $T_{1}$ and $T_{2}$. Conversely, the $T_{1}$ and $T_{2}$ groups in farms 2 and 3 benefited the most with the use of the halothane free gene semen. In addition, the results obtained on LSBBA and LSW in this study could be due to the effect of the probiotic in the feed of the sows which could have resulted in probiotic being vertically transferred from the sows to the piglets thus increasing the number of piglets that survived up to birth and up to weaning age (Taveros \& More 2005, Noguera et al 2002).

Table 2. Mean Litter Size at Birth Born Alive \& Litter Size at Weaning of the piglets in the three treatment groups in the farms

\begin{tabular}{|c|c|c|c|}
\hline Parameters and Treatments & Farm 1 & Farm 2 & Farm 3 \\
\hline \multicolumn{4}{|c|}{ Mean Litter Size at Birth Born Alive LSBBA (Number of heads) } \\
\hline $\mathrm{T}_{0}$ & 9.5 & 9.42 & 9.42 \\
\hline $\mathrm{T}_{1}$ & 9.5 & 9.42 & 9.33 \\
\hline $\mathrm{T}_{2}$ & 9.5 & 9.42 & 9.17 \\
\hline
\end{tabular}


Table 2. continued

\begin{tabular}{cccc}
\hline Parameters and Treatments & Farm 1 & Farm 2 & Farm 3 \\
\hline \multicolumn{4}{c}{ Mean Litter Size at Weaning LSW (Number of heads) } \\
\hline $\mathrm{T}_{0}$ & 9.42 & 8.57 & \\
$\mathrm{~T}_{1}$ & 9.50 & 9.25 & 9.25 \\
$\mathrm{~T}_{2}$ & 9.50 & 9.42 & 9.33 \\
\hline
\end{tabular}

Table 3. Mean Litter Size at Birth Born Alive \& Litter Size at Weaning of the piglets in three farms

\begin{tabular}{|c|c|}
\hline Parameters and Treatments & DAS-CAFS, Gaas and Tabgas Piggery Farm \\
\hline \multicolumn{2}{|c|}{ LSBBA (count, number of heads) } \\
\hline $\mathrm{T}_{0}$ & $9.67^{b}$ \\
\hline $\mathrm{T}_{1}$ & $10.67^{a}$ \\
\hline $\mathrm{T}_{2}$ & $10.92^{a}$ \\
\hline \multicolumn{2}{|c|}{ LSW (count, number of heads) } \\
\hline $\mathrm{T}_{0}$ & $9.25^{b}$ \\
\hline $\mathrm{T}_{1}$ & $10.67^{a}$ \\
\hline $\mathrm{T}_{2}$ & $10.92^{a}$ \\
\hline
\end{tabular}

Means with the same letters are not significantly different from each other at $p<0.05$ significant level

\section{Litter Weight at Birth (LWB) and Litter Weight at Weaning (LWW)}

The univariate analysis of variance showed that the treatments caused significant differences $(p<.05)$ in LWB $(\mathrm{kg})$. Tukey HSD analysis revealed that the mean LWB (kg) of $T_{2}$ in the three Farms - (1.46) and $T_{1}$ (1.43) were significantly higher than $\mathrm{T}_{0}$ (1.33) (Table 4). This trend was the same for the three farms, except in Farm 1 that the mean $\operatorname{LWB}(\mathrm{kg})$ of $\mathrm{T}_{2}$ was significantly higher both $\mathrm{T}_{1}$ and $\mathrm{T}_{0}$.

In terms of the frequency and relative frequency of the individual birth weight of the piglets in each treatment, in general, the lowest and highest birth weights obtained ranged $0.5-1.00 \mathrm{~kg}$ for the $T_{0}$ and $1.51-2.00 \mathrm{~kg}$ range for the $T_{1}$ to $T_{2}$. While, $T_{0}$ to $T_{1}$ and $T_{1}$ to $T_{2}$ the number of piglets in the lowest birth weight range decreased while those in the highest range increased (Table 4). This trend was similar in the three farms.

Table 4. Mean Litter Weight at Birth and Litter Weight at Weaning of the three treatments in the three farms

\begin{tabular}{cccc}
\hline $\begin{array}{l}\text { Parameters } \\
\text { and Treatments }\end{array}$ & Farm 1 & Farm 2 & Farm 3 \\
\hline \multicolumn{4}{c}{ Mean Litter Weight at Birth (LWB in kg) } \\
\hline $\mathrm{T}_{0}$ & $1.43^{b}$ & $1.31^{b}$ & $1.26^{b}$ \\
$\mathrm{~T}_{1}$ & $1.46^{b}$ & $1.42^{\mathrm{a}}$ & $1.41^{\mathrm{a}}$ \\
$\mathrm{T}_{2}$ & $1.50^{\mathrm{a}}$ & $1.44^{\mathrm{a}}$ & $1.45^{\mathrm{a}}$ \\
\hline \multicolumn{4}{c}{ Mean Litter Weight at Weaning $(\mathrm{LWW} \mathrm{in} \mathrm{kg)}$} \\
\hline $\mathrm{T}_{1}$ & $7.19^{c}$ & $6.16^{c}$ & $6.16^{c}$ \\
$\mathrm{~T}_{2}$ & $7.81^{b}$ & $7.12^{b}$ & $6.98^{b}$ \\
\hline
\end{tabular}

Means with the same letters are not significantly different from each other 
Reproduction performance of sows inseminated with stress gene-free semen

Pre-weaning Mortality (PWM)

Extending the results of LSBBA and LSW, the PWM (\%) was computed from the means of the two parameters (Arango et al 2005). PWM showed a decreasing trend in $T_{0}$ to $T_{1}$ and $T_{2}$. Specifically, $T_{0}, T_{1}$ and $T_{2}$ in Farm 1 , had $0.84 \%, 0 \%$ and $0 \%$, respectively while Farm 2, had $7.97 \%, 2.40 \%$ and $0 \%$; and Farm 3 , had $10.67 \%, 0 \%$ and $0 \%$. In Farms 1 and $3, \mathrm{~T}_{1}$ and $\mathrm{T}_{2}$ had no mortality while $\mathrm{T}_{1}$ in Farm 2 had a PWM of $2.40 \%$ indicating pre-weaning deaths in this group.

\section{Sow Performance}

\section{Lactational Weight Loss (LWL)}

The mean lactational weight loss of sows in the treatment groups in the three farms decreased from $T_{0}$ to $T_{1}$ and from $T_{1}$ to $T_{2}$ with the biggest weight loss in the $T_{0}$ sows and the lowest, in $T_{2}$ sows. In the $T_{0}$ sows, mean weight loss was $23 \mathrm{~kg}, 23.50 \mathrm{~kg}$ and $23.54 \mathrm{~kg}$. In $\mathrm{T}_{1}$ sows, weight loss was $21.21 \mathrm{~kg}, 21.54 \mathrm{~kg}$ and $21.79 \mathrm{~kg}$, respectively; while in the $T_{2}$ sows, weight loss was $18.50 \mathrm{~kg}, 20.46 \mathrm{~kg}$ and $20.08 \mathrm{~kg}$, respectively (Table 5).

The univariate ANOVA showed differences in terms of the mean weight loss during lactation. The results of the Tukey's HSD showed the same trend in the three farms in that the mean weight loss of the $T_{0}$ sows was significantly higher than that in the $T_{1}$ sows which was also significantly higher than that in the $T_{2}$ sows.

Table 5. Mean Lactational Weight Loss, Service per Litter, Weaning-to-Conception Interval and Breeding to Breeding Interval of the treatment sows in the three farms

\begin{tabular}{|c|c|}
\hline Parameters and Treatments & DAS-CAFS, Gaas and Tabgas Piggery Farms \\
\hline $\mathrm{LWL}(\mathrm{kg})$ & Mean \\
\hline $\mathrm{T}_{0}$ & $23.54^{c}$ \\
\hline $\mathrm{T}_{1}$ & $21.79^{b}$ \\
\hline $\mathrm{T}_{2}$ & $20.08^{a}$ \\
\hline SPL (count) & Mean \\
\hline $\mathrm{T}_{0}$ & $3.33^{b}$ \\
\hline $\mathrm{T}_{1}$ & $1.00^{a}$ \\
\hline $\mathrm{T}_{2}$ & $1.00^{a}$ \\
\hline WCl (days) & Mean \\
\hline $\mathrm{T}_{0}$ & $22.42^{b}$ \\
\hline $\mathrm{T}_{1}$ & $11.25^{a}$ \\
\hline $\mathrm{T}_{2}$ & $9.42^{a}$ \\
\hline BBI (days) & Mean \\
\hline $\mathrm{T}_{0}$ & $169.17^{b}$ \\
\hline $\mathrm{T}_{1}$ & $154.33^{a}$ \\
\hline $\mathrm{T}_{2}$ & $152.33^{a}$ \\
\hline $\begin{array}{l}\text { Predominance of } E \text {. coli in sow's } \\
\text { pooled milk sample }\end{array}$ & Mean \\
\hline $\mathrm{T}_{0}$ & $8^{b}$ \\
\hline $\mathrm{T}_{1}$ & $3^{a}$ \\
\hline $\mathrm{T}_{2}$ & $4^{a}$ \\
\hline
\end{tabular}


Weaning-to-Conception Interval (WCI) and Number of Service per Litter (SPL)

It is worth mentioning that around $50 \%$ of the sows in $T_{1}$ were successfully mated in less than 10 days. This could mean that while $2 \mathrm{~g}$ of probiotic/kilogram feed was able to prevent repeated service in the sows, this level was able to contribute in bringing the sows into heat $<10$ days post weaning.

\section{Conception Rate at First Service}

In three piggery farms, $33.33 \%$ or 4 of the $12 \mathrm{~T}_{0}$ sows conceived at first Al while 8 did not. However, in the $T_{1}$ and $T_{2}$ sows, all sows conceived at first $\mathrm{Al} 100 \%$, meaning all the 12 sows conceived at first Al.

\section{Breeding to Breeding Interval (BBI), Litters Produced and Pigs Produced per Sow per Year}

As expected, $\mathrm{BBI}$ in this study followed the same trend with the WCI. The univariate ANOVA showed treatment differences in the BBI and using Tukey's HSD for treatment comparisons, it was revealed that in the three farms, $B B I$ of the $T_{0}$ sows was significantly different from that of $T_{1}$ and $T_{2}$ however, between $T_{1}$ and $T_{2}$, there was none.

In terms of the frequency distribution of the BBI of individual sows, majority of the $T_{0}$ sows had $B B I$ in the range of 171-175 days; majority of the $T_{1}$ sows were in the range of 146-150 days, and finally, majority of $\mathrm{T}_{2}$ (10 or $83.33 \%$ ) had $151-155$ days.

In terms of pigs produced per sow per year (PPSY), the univariate ANOVA showed differences and the results of Tukey's HSD revealed differences between $T_{0}$ and $T_{1}$ and $T_{0}$ and $T_{2}$ but not between $T_{1}$ and $T_{2}$. The difference between and among treatments in terms of PPSY was significant (Table 6). Compared to what was reported by Lapus (2009), these findings suggest that even at the rate of $2 \mathrm{~g}$ probiotic/kilogram feed combined with halothane free gene semen for $\mathrm{Al}$ is effective in producing stress-tolerant piglets.

Table 6. Mean litters and pigs produced per sow per year

\begin{tabular}{cc}
\hline \multicolumn{2}{c}{ Litters produced per sow per year (Number of Parity) } \\
\hline Treatment & DAS-CAFS, Gaas and Tabgas Piggery Farms \\
\hline$T_{0}$ & 2.16 \\
$T_{1}$ & 2.37 \\
$T_{2}$ & 2.40 \\
\hline \multicolumn{2}{c}{ Pigs produced per sow per year (Number of heads) } \\
\hline$T_{0}$ & $19.96^{b}$ \\
$T_{1}$ & $25.23^{\mathrm{a}}$ \\
$\mathrm{T}_{2}$ & $26.16^{\mathrm{a}}$ \\
\hline
\end{tabular}


Reproduction performance of sows inseminated with stress gene-free semen

Cost of AI Using Farm Boar Semen or halothane free gene semen and Probiotic or Infeed Antibiotics

\section{Cost of Al}

The cost of Al per conception of the $T_{0}, T_{1}$ and $T_{2}$ sows, the difference in the cost of Al per conception of each sow was PHP1,500.00 (single dose farm practice) and PHP1,418.74 (two doses halothane free gene semen).

\section{Cost of Probiotic or In-Feed Antibiotics}

The computed cost of feed and antibiotics or probiotics in the treatment groups in the three farms were the same amounting to PHP282,397.24.

\section{CONCLUSIONS}

In view of the results obtained in this study, the following conclusions are drawn:

1.The probiotic, both at $2 \mathrm{~g}$ and $3 \mathrm{~g} \mathrm{~kg}^{-1}$ feed is effective in improving both litter and sow performance.

2.Cost of using halothane free gene semen for $\mathrm{Al}$ is relatively cheaper than using the farm's boar. Likewise, the cost of using probiotic at the two levels as feed additive is relatively cheaper than using antibiotics based on the pre-weaning mortality, litter size and litter weight at weaning records.

3.The offsprings of halothane free gene semen are highly resistant to diarrhea and produce very fast-growing weanlings, hence, requiring less utilization of veterinary drugs or antibiotics.

\section{RECOMMENDATIONS}

Further research need to be conducted to provide us deeper information about the effect of halothane free gene semen and the use of probiotics. Some of these studies include:

1. Study to be conducted on Gene Transfer Corporation piglets in terms of disease resistance and productivity performance.

2. Study on GTC piglets is subjected to test for meat tenderness, back fat thickness and gene mapping.

3. Separate study of sow's gene frequency of the $n$ allele of the hal gene should also be used as basis of the grouping to get more specific and reliable results.

4. Litter production performance test must extend until marketing to determine the effect of using halothane free gene semen or stress gene-positive boar on other parameters affected by stress tolerance of pigs. In addition, because the Philippines is a tropical country and most pig farms are predisposed to various diseases, future studies should include effect of using semen of halothane free gene boar on disease resistance of the litters of sows. 


\section{ETHICAL CONSIDERATION}

All animals were treated humanely according to the principles of Animal Welfare Act. of the Philippines (RA 8485) and guidelines set by the Bureau of Animal Industry of the Philippines. This study was approved by the approving body the Department Research Committee of the Department of Animal Science, College of Agriculture, Visayas State University.

\section{ACKNOWLEDGMENT}

Great appreciation to the farm owners of Ga-as and Tabgas piggery farms, the Pig Improvement Company (PIC) for the GTC-semen and logistic support through The Gene-Transfer Corporation especially to Dr. Neil Barry, Dr. Manny Caintic and the PIC staff. The Visayas State University funded the research.

\section{REFERENCES}

Altemueller U, Broz J \& Brugger R. 2009. Optimizing performance and health of sows and piglets. Pig Progress 25(4)

Arango J, Misztal I, Tsuruta S, Culbertson M \& Herring W. 2005. Threshold-linear estimation of genetic parameters for farrowing mortality, litter size, and test performance of large white sows. Journal of Animal Science 83(4):499-506

Bastos RG, Federzzi J, Deschamps JC, Cardellino R \& Dellagostin OA. 2000. Characterization of swine stress gene by DNA testing using plucked hair as a source of DNA. Genetic Molecular Biology 23(4):815-817

Bidanel JP, Caritez JC, Gruand J \& Legault C. 2020. Growth, carcass and meat quality performance of crossbred pigs with graded proportions of Meishan genes. Genetics Selection Evolution 25(1):83-99

Böhmer BM, Kramer W \& Roth-maier DA. 2006. Dietary probiotic supplementation and resulting effects on performance, health status, and microbial characteristics of primiparous sows. Journal of Animal Physiology and Animal Nutrition 90(7-8):309-315

Clutter AC, Buchanan DS \& Luce WG. 2007. Evaluating Breeds of Swine for Crossbreeding Programs. Fact Sheet from Oklahoma Cooperative Extension Service. The Pig Site. https://www.thepigsite.com/articles/evaluating-breedsof-swine-for-crossbreeding-programs

de Smet SM, Pauwels H, De Bie S, Demeyer DI, Callewier J \& Eeckhout W. 1996. Effect of halothane genotype, breed, feed withdrawal and lairage on pork quality of Belgian slaughter pigs. Journal of Animal Science 74(8):1854-1863

Estienne MJ, Hartsock TG \& Harper AF. 2005. Effects of Antibiotics and Probiotics on Suckling Pig and Weaned Pig Performance. International Journal of Applied Research in Veterinary Medicine 3(4):303-308

Fàbrega E, Manteca X, Font J, Gisperta M, Carriónd D, Velarde A, Ruiz-de-la-Torre JL \& Diestrea A. 2002. Effects of halothane gene and pre-slaughter treatment on meat quality and welfare from two pig crosses. Meat Science 62(4):463-72

Fisher P, Mellett FD \& Hoffman LC. 2000. Halothane Genotype and Pork Quality. 2. Cured Meat Products of Three Halothane Genotypes. Meat Science 54(2):107111 


\section{Reproduction performance of sows inseminated with stress gene-free semen}

Garcia-Macias JA, Gispert M, Oliver MA, Diestre A, Alonso P, Munoz-Luna A, Siggens $K$ \& Cuthbert-Heavens D. 2010. The effects of cross, slaughter weight and halothane genotype on leanness and meat and fat quality in pig carcasses. Animal Science 63(3):487-496

Ho SK. 2004. What are Probiotics. Centre for Food and Animal Research. Research Branch Agriculture \& Agri-Food Canada, Ohttawa, Ontario, Canada, K1AOC6

Jacela JY, Derouchey JM, Tokach MD, Goodb RD, Nelssen JL, Renter DG \& Driz SS. 2010. Feed additives for swine: Fact sheets - prebiotics and probiotics, and phytogenics. Journal of Swine Health and Production 18(3):132-136

Kathirvel P and Archibald AL. 2001. The Halothane Gene, Leanness and Stress Susceptibility in Pigs. In Owen JB, Treasure JL \& Collier DA (eds) Animal Models - Disorders of Eating Behaviour and Body Composition (pp173-190). Springer, Dordrecht

Knox RV. 2000. Artificial Insemination of Swine: Improving Reproductive Efficiency of the Breeding Herd. Department of Animal Sciences, University of Illinois at Urbana-Champaign, Urbana, Illinois, USA

Lapuz ZM. 2009. Swine production in the Philippines (What the Experts Say).https://www.pig333.com/articles/swine-production-in-the-philippines-22_1489/

Larzul C, Le Roy P, Gueblez R, Talmant A, Gogue J, Sellier P \& Monin G. 1997. Effect of halothane genotype (NN, Nn, nn) on growth, carcass and meat quality traits of pigs slaughtered at $95 \mathrm{~kg}$ or $125 \mathrm{~kg}$ live weight. Journal Animal Breed Genetics 114(1-6):309-20

Marriott NG and Schilling MW. 2006. Utilization of pale, soft, and exudative pork. Pork Information Gateway. http://porkgateway.org/resource/utilization-of-pale-softand-exudative-pork

Noguera JL, Varona L, Babot D \& Estany J. 2002. Multivariate analysis of litter size for multiple parities with production traits in pigs: I. Bayesian variance component estimation. Journal of Animal Science 80(10):2540-2547

Schrezenmeir $\mathrm{J}$ and de Vrese M. 2001. Probiotics, prebiotics, and synbiotics approaching a definition. American Journal of Clinical Nutrition 73(2):361S$364 s$

Simon 0. 2005. Micro-Organisms as Feed Additives - Probiotics. Advances in Pork Production: Proceedings of the 1995BanffPork Seminar 16:161-167

Taras WV and Simon O. 2007. Probiotics in pigs - modulation of their intestinal distribution and of their impact on health and performance. Livestock Science 108(1-3):229-231

Taveros AA and More S. 2005. Field Trial on Sow Productivity. Preventive Veterinary Medicine 46(4-5):135-148

ter Beek V. 2009. Stress Free Pigs. The gateway to the world of pig production. www.pigprogress.net/sevents. Retourades: Reed Business Media Postbus 808,7000 AV Doetinchen, The Netherlands. Pig Progress 26(7)

Zhang W, Kuhlers DL \& Rempel WE. 1992. Halothane gene and swine performance. Journal of Animal Science 70(5):1307-1313 